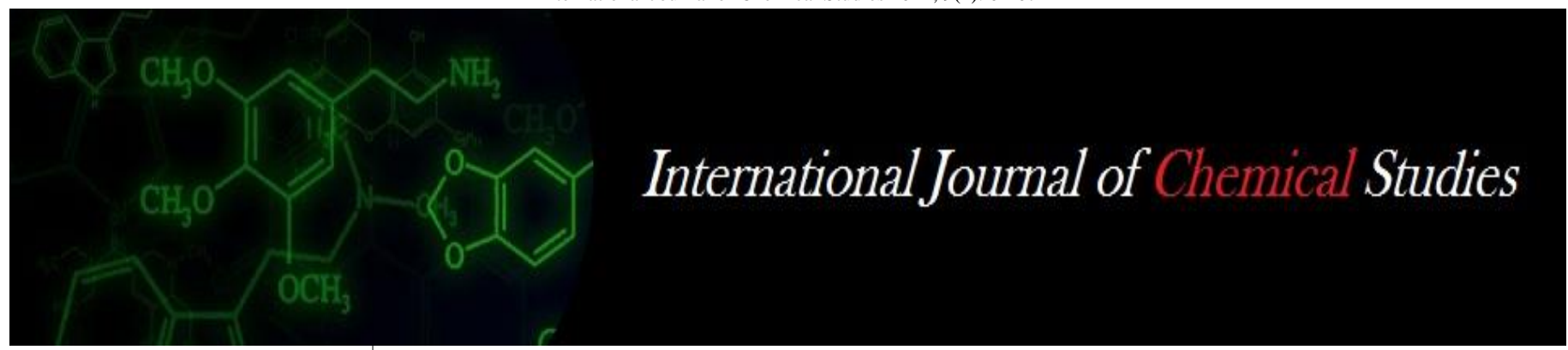

P-ISSN: 2349-8528

E-ISSN: 2321-4902

www.chemijournal.com

IJCS 2021; 9(1): 01-07

(C) 2021 IJCS

Received: 01-11-2020

Accepted: 04-12-2020

\section{R Ara}

Principal Scientific Officer,

Regional Spice Research Centre,

BARI, Joydebpur, Dhaka,

Bangladesh

\section{AC Deb}

Professor, Department of

Genetic Engineering and

Biotechnology, University of

Rajshahi, Rajshahi-6205,

Bangladesh
Corresponding Author:

AC Deb

Professor, Department of

Genetic Engineering and

Biotechnology, University of

Rajshahi, Rajshahi-6205,

Bangladesh

Email:

anil deb2001@yahoo.com

debac@ru.ac.bd

\title{
Combining ability and gene action of four seed yield contributing characters in onion (Allium cepa L.)
}

\section{R Ara and AC Deb}

DOI: https://doi.org/10.22271/chemi.2021.v9.i1a.11189

\section{Abstract}

For the improvement of onion seed yield mode of gene action is essential to know. Significant D indicated additive variations were greater in magnitude except umbel diameter and significant $\mathrm{H}_{1}$ indicated dominant variation for scape height and umbel diameter. Significant F indicating the presence of dominant genes only in number of umbel. $\mathrm{H}_{2}$ component is non-significant for all the characters except scape height. Non-significant $\mathrm{h}^{2}$ suggested dominance effect over all loci in the heterozygous phase was not important for number of umbel, scape height and umbel volume. Ratio $\left[\left(4 \mathrm{DH}_{1}\right)^{1 / 2}+\mathrm{F}\right] /\left[\left(4 \mathrm{DH}_{1}\right)^{1 / 2}-\right.$ $\mathrm{F}]$ is greater than one for umbel volume indicated presence of an excess of dominant genes in the parents. For all the characters, ratio $\mathrm{h}^{2} / \mathrm{H}_{2}$ smaller than one indicated the involvement of at least one group of dominant genes. Parent $\mathrm{P}_{4}$ observed as good general combiner, $\mathrm{F}_{1}\left(\mathrm{P}_{3} \times \mathrm{P}_{4}, \mathrm{P}_{1} \times \mathrm{P}_{2}, \mathrm{P}_{1} \times \mathrm{P}_{4}, \mathrm{P}_{1} \times \mathrm{P}_{5}\right.$ and $\mathrm{P}_{1}$ $\left.\times \mathrm{P}_{3}\right)$ and reciprocal crosses $\left(\mathrm{P}_{2} \times \mathrm{P}_{1}, \mathrm{P}_{3} \times \mathrm{P}_{1}\right.$ and $\left.\mathrm{P}_{4} \times \mathrm{P}_{1}\right)$ for different traits recorded as the good specific combiners. So, this parent, $F_{1}$ and reciprocal crosses need to special consideration for the improvement of onion yield.

Keywords: Diallel, gene action, GCA, SCA, onion

\section{Introduction}

Onion (Allium cepa L.) a member of the family Alliaceae is one of the most important spice crops grown all over the world. It is popularly used both at immature and mature bulb stages as a vegetable as well as spice and an indispensable item in every kitchen. The use of onion is not limited to any climate or associated with nationality. It is an important ingredient in several cooked vegetables and is used for their flavor, aroma and taste in the preparation of different dishes. Fresh onions contain about $86.8 \%$ moisture, $11.6 \%$ carbohydrates including 6 to $9 \%$ soluble sugars, $1.2 \%$ protein, $0.1 \%$ fat, 0.2 to $0.5 \%$ calcium, $0.05 \%$ phosphorus and traces of $\mathrm{Fe}, \mathrm{Al}, \mathrm{Cu}, \mathrm{Zn}, \mathrm{Mn}$ and I. Vitamin $\mathrm{A}, \mathrm{B}_{1}, \mathrm{~B}_{2}, \mathrm{C}$ and nicotinic acid are present as $2.6 \mathrm{IU}, 64 \mathrm{mg}$, $79 \mathrm{mg}, 0.77 \mathrm{mg}$ per 100g onion, respectively (Manjunath, 1948; Brahmachari and Augusti, 1962) ${ }^{[26,7]}$. According to traditional medical literature (Nadkarni, 1954) ${ }^{[29]}$, onions are a source of many vitamins and are useful in fever, dropsy catarrh and chronic bronchitis. Onion has diuretic properties, beneficial to the digestive tract, good for the eyes, to act as a heart stimulant and useful as an anti-rheumatic remedy. It has a lipid-lowering effect. Augusti (1974) ${ }^{[4]}$ reported that regular use of onion by a diabetic patient lowered his insulin dosage considerably. Onion can be stored after harvest and can be disposed of later in the market at the time when the prices are in favour of the growers. There is thus a lesser risk of overproduction in onion than in most other vegetables, which have to be marketed at once after harvest (Pandey and Singh, 1993) ${ }^{[30]}$.

Among the spice grown in Bangladesh, onion is grown in 1.79 lakh hectares and produced 17.38 lakh $\mathrm{mt}$ in terms of area and production (BBS, 2018) ${ }^{[6]}$. The average bulb yield of onion is very low as $6.93 \mathrm{t} / \mathrm{ha}$ when compared to the world average yield as $17.10 \mathrm{t} / \mathrm{ha}$ (FAO, 2001) ${ }^{[12]}$. Simultaneously, the seed yield of onion is very low as 370 to $500 \mathrm{~kg} / \mathrm{ha}$ (HRDP, 1995) [21] when compared to the yield as 1000 to $1200 \mathrm{~kg} / \mathrm{ha}$ of some other countries of the world (Brewster, 1994) ${ }^{[8]}$. The total production of onion seed is about $150 \mathrm{mt} /$ year but its requirement is more than $300 \mathrm{mt}$ (Rahim, 1991) ${ }^{[34]}$. Though the area, per acre yield and production increases in the subsequent year (BBS, 2018) ${ }^{[6]}$ but still now Bangladesh is not sufficient in 
onion production as per the demand of her population. The use of old varieties like Taherpuri, Faridpuri, Jhitka etc. is one of the most important reasons for low productivity. So, the country needs to import a large quantity of onion every year and expend a huge amount of money for that. Mila and Parvin (2019) ${ }^{[28]}$ reported that the yield level of onion is quite low (approximately $370-500 \mathrm{~kg} / \mathrm{ha}$ ) as compared to the higher yield (1000-1200 kg/ha) produced in other countries and this is happening due to lack of quality seed and improved varieties as well as improper cultural practices.

Looking at the importance and production of this crop greater attention is needed for its improvement. Therefore, efforts should be made to develop high yielding varieties through breeding research. But the success of the breeding programme depends on the knowledge of genetic variability of a population, about the nature and different gene actions governing the various quantitative traits. Most agronomic and economic characters are quantitative in nature and show continuous variation, which might be produced by a multitude of individual genes, each with a small effect. Studies of these characters are done by standard biometrical techniques of Hayman (1954a) ${ }^{[15]}$, Hayman (1954b) ${ }^{[16]}$ and Griffing (1956) [14] approaches. Genetic information of onion is not available, as little or no work has been done in this regard in Bangladesh. Therefore, the present study was undertaken to determine the mode of gene action in governing seed yield contributing characters and also to generate information for the identification of good general and specific combiners for the improvement of onion seed yield and its attributes.

\section{Materials and Methods}

The four released varieties viz. BARI Piaz-1, BARI Piaz-2, BARI Piaz-3 and BARI Piaz-4 and one promising line (ON0256) of onion collected from Spices Research Center (SRC), Bangladesh Agricultural Research Institute (BARI), Bogura were used in the present experiment as materials. Among them, BARI Piaz-1 $\left(\mathrm{P}_{1}\right)$, BARI Piaz-4 $\left(\mathrm{P}_{4}\right)$ and ON0256 $\left(\mathrm{P}_{5}\right)$ are winter varieties and BARI Piaz-2 $\left(\mathrm{P}_{2}\right)$ and BARI Piaz-3 $\left(\mathrm{P}_{3}\right)$ are summer varieties. The experiment was set up in a randomized complete block design with three replications. Twenty cross combinations for $F_{1}$ seed production as well as 5 parents (produced by selfing) were considered as 25 treatments in the trial. For the production of $F_{1}$ seeds, two rows per plot having $1 \mathrm{~m}$ long and $30 \mathrm{~cm}$ space between them and plants to plant distanced were $20 \mathrm{~cm}$ in the rows. Of the three replications, each contained 20 plots with 10 plants in each. Hybridization and selfing were done following full diallel fashion. Selfing was done by putting individual bamboo made frames with cotton net (20 mesh) over the plants as soon as the first flower opened. Then flies were introduced to ensure pollination. Besides, after anthesis the umbels were rubbed against each other daily for a few days to ensure self-pollination. Individual bamboo made frame fitted on each plot where onion bulbs of two parents planted and cotton net (20 meshes) fixed over the frame in each combination of parents in one plot during the flowering stage to check cross-pollination. Emasculation was done prior to anthesis. Then, for a few days in the morning, the male umbel was gently rubbed over the emasculated umbel (female parent) to ensure pollen shedding and cross-pollination. Simultaneously, flies were introduced into the individual net to encourage pollination between two parents. The introduction of flies in the net was continued up to the formation of seeds. The seeds of $F_{1}$, reciprocals and parents were kept separately in the polythene packet and preserved in the refrigerator.

Data on four seed production related characters such as number of umbel, scape height, umbel diameter and umbel volume were recorded from 5 randomly selected plants of each plot and the collected data were analyzed according to Hayman (1954a) ${ }^{[15]}$, Hayman (1954b) ${ }^{[16]}$ and Griffing (1956) [14] approaches. Techniques of analyses of the data are described under the following sub-heads:

\section{i). Testing the significance differences}

The data were first analyzed to test the significance of crossing differences. The total variability in the treatments was partitioned into components like variance due to replication, crosses (including parents), interaction $(\mathrm{C} \times \mathrm{R})$ and within error.

The sums of squares are calculated as follows:

Correction factor $=(\text { Grand total })^{2} / \mathrm{r} \times(\mathrm{n} \times \mathrm{n}) \times \mathrm{s}$

Total $_{\text {ss }}=$ Individual observation ${ }^{2}-\mathrm{CF}$

Treatment $s s=\sum \mathrm{X}_{\mathrm{i}}^{2} / \mathrm{s}-\mathrm{CF}$

Replication $_{S S}=\frac{\sum \mathrm{X}_{\mathrm{j}}^{2}}{\mathrm{c} \times \mathrm{s}}-\mathrm{CF}$

Cross (including parents) $\mathrm{ss}=\sum \mathrm{X}_{\mathrm{k}}{ }^{2} / \mathrm{rs}-\mathrm{CF}$

$\mathrm{C} \times \mathrm{R}_{\mathrm{ss}}=$ Total $_{\mathrm{ss}}-$ Treatment $_{\mathrm{ss}}-$ Replication $_{\mathrm{ss}}$

Within error ss $=$ Total $s s-$ Treatment ss

Here, $X_{i}=$ replication total, $X_{j}=$ treatment total, $X_{k}=$ cross (including parents) total, $\mathrm{r}=$ number of replications, $\mathrm{n}=$ number of parents, $\mathrm{c}=$ number of crosses $(\mathrm{n} \times \mathrm{n})$ and $\mathrm{s}=$ number of plants or sibs.

\section{ii). Combining ability analysis}

ANOVA for combining ability analysis has been done using method 1 (Griffing, 1956) ${ }^{[14]}$. Sum of squares due to GCA, SCA and reciprocals and their GCA $\left(\mathrm{g}_{\mathrm{i}}\right)$, SCA $\left(\mathrm{s}_{\mathrm{ij}}\right)$ and reciprocals $\left(\mathrm{r}_{\mathrm{ij}}\right)$ effects are obtained as follows:

$$
\begin{aligned}
& \text { GCA }_{S S}=\frac{1}{2 n}\left[\sum(Y i .+Y . j)^{2}-\frac{2}{n} Y_{. .}{ }^{2}\right] \\
& \text { SCA }_{S S}=1 / 2 \sum \sum Y_{i j}\left(Y_{i j}+Y_{j i}\right)-1 / 2 n \sum\left(Y_{. j}+Y_{i .}\right)^{2}+1 / n^{2} Y^{2} . . \\
& \text { Reciprocal }_{S S}=1 / 2 \sum \sum\left(Y_{i j}-Y_{j i}\right)^{2} \\
& g_{i} \text { effect }=1 / 2 n\left(Y_{i .}+Y_{. j}\right)-1 / n^{2} Y . . \\
& s_{i j} \text { effect }=1 / 2\left(Y_{i j}+Y_{j i}\right)-1 / 2 n\left(Y_{i .}+Y_{. i}+Y_{j .}+Y_{j j}\right)+1 / n^{2} Y . . \\
& r_{i j} \text { effect }=1 / 2\left(Y_{i j}-Y_{j i}\right)
\end{aligned}
$$

\section{iii). Estimation of variance and covariances}

First and second degree statistics (Mather, 1949) ${ }^{[27]}$ were calculated from the mean data. With the environmental expectations (E) included, the statistics of the above parameters may be shown as follows (Hayman, 1954b) ${ }^{[16]}$ : 
Parental mean $=\frac{\text { Sum of all the diagonal values }}{\text { Number of parents }}$

$$
\begin{aligned}
& \mathrm{V}_{0} \mathrm{~L}_{0}=\frac{1}{\mathrm{n}-1}\left[\sum \text { Diagonal values }^{2}-\frac{\left(\sum{\text { Diagonal values })^{2}}_{\text {Number of diagnoal values }}\right.}{\text { Number }}\right. \\
& \mathrm{V}_{\mathrm{r}}=\frac{1}{\mathrm{n}-1}\left[\sum \text { Crossesinvolvinga particularparent }{ }^{2}-\frac{\left(\sum \text { Corssesinvolvinga particulapparent }\right)^{2}}{\text { Numof parents }}\right]
\end{aligned}
$$

$$
\mathrm{V}_{1} \mathrm{~L}_{1}=\frac{1}{\mathrm{n}} \sum \mathrm{V}_{\mathrm{ri}}
$$$$
\left.\mathrm{W}_{\mathrm{r}}=\frac{1}{\mathrm{n}-1}\left[\sum \text { Arrays } \times \text { no }- \text { recuring parents }\right)-\frac{\sum \text { Arrays } \sum \text { Digonal values }}{\text { Number of parents }}\right]
$$

$$
\mathrm{W}_{0} \mathrm{~L}_{01}=\frac{1}{\mathrm{n}} \sum \mathrm{W}_{\mathrm{ri}}
$$$$
\mathrm{V}_{0} \mathrm{~L}_{1}=\frac{1}{\mathrm{n}-1}\left[\sum \text { Array means }{ }^{2}-\frac{\left(\sum \text { Array means }\right)^{2}}{\text { Number of arrays }}\right]
$$

$\left(\mathrm{ML}_{1}-\mathrm{ML}_{0}\right)^{2}=\left[\frac{1}{\mathrm{n}}\left\{\frac{1}{\mathrm{n}} \text { Grand total }- \text { Diagonal values }\right\}\right]^{2}$

$$
\mathrm{E}=1 / \mathrm{r}\left\{\frac{\text { Interactio } \mathrm{n} \text { Error ss }+ \text { Within Error ss }+ \text { Rep ss }}{\text { Interactio } \mathrm{n} \text { Error } \mathrm{df}+\text { Within Error }+ \text { Rep.df }}\right\}
$$

\section{iv). Components of variation and their proportions}

The expected values of the components of variation obtained by least square computations are as follows:

$$
\begin{aligned}
& \mathrm{D}=\mathrm{V}_{0} \mathrm{~L}_{0}-\mathrm{E} \\
& \mathrm{F}=2 \mathrm{~V}_{0} \mathrm{~L}_{0}-4 \mathrm{~W}_{0} \mathrm{~L}_{01}-2(\mathrm{n}-2) \mathrm{E} / \mathrm{n} \\
& \mathrm{H}_{1}=\mathrm{V}_{\mathrm{oLo}}-4 \mathrm{~W}_{\mathrm{oLo}}+4 \mathrm{~V}_{1 \mathrm{~L} 1}-(3 \mathrm{n}-2) \mathrm{E} / \mathrm{n} \\
& \mathrm{H}_{2}=4 \mathrm{~V}_{1} \mathrm{~L}_{1}-4 \mathrm{~V}_{0} \mathrm{~L}_{1}-2 \mathrm{E} \\
& \mathrm{h}^{2}=4\left(\mathrm{ML}_{1}-\mathrm{ML}_{0}\right)^{2}-4(\mathrm{n}-1) \mathrm{E} / \mathrm{n}^{2}
\end{aligned}
$$

For testing the significance of each of these above components, respective standard errors were calculated.

Another proportional values were measured as follows:

Degree of dominance $=\left(\mathrm{H}_{1} / \mathrm{D}\right)^{1 / 2}$

Proportion of genes with positive and negative effects in the parents $=\mathrm{H}_{2} / 4 \mathrm{H}_{1}$

Proportion of dominant and recessive genes in the parents = $\left.\left.\left[4 \mathrm{D} \mathrm{H}_{1}\right)^{1 / 2}+\mathrm{F}\right] /\left[4 \mathrm{D} \mathrm{H}_{1}\right)^{1 / 2}-\mathrm{F}\right]$

The number of groups of genes which control the character and exhibit dominance $=\mathrm{h}^{2} / \mathrm{H}_{2}$

Estimates the order of dominance of the parents $=\mathrm{V}_{1} \mathrm{~L}_{1} /$ $\mathrm{W}_{0} \mathrm{~L}_{01}$

\section{Results and Discussion}

According to Hayman (1954b) ${ }^{[16]}$, the results of the analysis of variance (ANOVA) of five-parent full diallel for testing the significant differences among crosses including parents is shown in Table 1. This analysis involved in partitioning the total variance into treatment, replication, crosses (including parents), crosses $\times$ replication $(\mathrm{C} \times \mathrm{R})$ and within error.

The above items in the table were tested against their both error mean squares viz., interaction and within error (Table 1). Pooled error was used in all the characters except umbel volume. The values of treatment were highly significant for all the characters indicated that crosses including parents were significantly different from each other and the values of replication was non-significant for number of umbel and umbel diameter. When scape height and umbel volume, respectively were tested against within error and interaction were found to be significant. The values of crosses were found to be highly significant in all the characters. As treatment MS was significant, therefore, further analyses were done.

For the combining ability analysis, Method-1 of Griffing's (1956) ${ }^{[14]}$ was considered. The variations due to GCA and SCA (Table 2) were found to be significant for all the studied traits indicating that both additive and non-additive gene actions played a significant role in the expression of these characters. Pathak and Gowda (1993) ${ }^{[32]}$ reported that scape height and many yield contributing characters of onion were controlled by both additive and non-additive gene action. Both GCA and SCA values in ANOVA were found to be significant by Ara et al., (2011) ${ }^{[3]}$ in onion, Farid et al., (2012) ${ }^{[13]}$ in shallot and Patil and Subramaniam (2020) ${ }^{[33]}$ in white onion. Reciprocal crosses were found to be significant for all the characters except umbel volume in this material.

The relative magnitude of GCA (Table 3) was higher than SCA for all the four characters in this material. It was observed from this table that parent $\mathrm{P}_{4}$ showed the highest positive significant GCA effects for different characters. So, $\mathrm{P}_{4}$ was noted as good general combiner for scape height, umbel volume and number of umbel followed by $\mathrm{P}_{5}$ for scape height and umbel volume and $\mathrm{P}_{1}$ only for the trait scape height. A positive and high magnitude of GCA effect was obtained by Mani et al., (1999) ${ }^{[25]}$ for bulb yield in onion. Farid et al., (2012) ${ }^{[13]}$ observed that genotypes Tiron and Timor displayed the highest GCA value on all characters except plant height and bulb diameter in shallot. Parents exotics JV16 and JV12 noted as good general combiner by Patil and Subramaniam (2020) ${ }^{[33]}$ for yield and processing quality characters in white onion. Hosfield et al., (1976, 1977a, 1977b) ${ }^{[18,19,20]}$ recorded large GCAs for yield, bulb quality, and maturity. On the other hand, significant GCAs was noted by Aghora and Pathak (1991) [1] and Joshi and Tandon (1976) ${ }^{[22]}$ in their studied materials.

Table 4 showed significant and non-significant positive and negative SCA values for $\mathrm{F}_{1}$ 's and reciprocals. In case of SCA effects due to $F_{1}$, higher positive significant values were obtained for scape height in $\mathrm{P}_{3} \times \mathrm{P}_{4}$ followed by scape height in $\mathrm{P}_{1} \times \mathrm{P}_{2}$, umbel volume in $\mathrm{P}_{1} \times \mathrm{P}_{4}$ and scape height in $\mathrm{P}_{1} \times$ $\mathrm{P}_{5}$ and $\mathrm{P}_{1} \times \mathrm{P}_{3}$. In this study, scape height showed the higher positive significant SCA effects in five combinations and cross $\mathrm{P}_{1} \times \mathrm{P}_{5}$ exhibited positive significant values for all the characters except umbel volume. On the other hand, higher significant positive SCA values were recorded for the reciprocal crosses in $\mathrm{P}_{2} \times \mathrm{P}_{1}$ and $\mathrm{P}_{3} \times \mathrm{P}_{1}$ for scape height and in $\mathrm{P}_{4} \times \mathrm{P}_{1}$ for umbel volume. Reciprocal cross $\mathrm{P}_{2} \times \mathrm{P}_{1}$ showed significant positive values for all the characters under study. Similarly, $\mathrm{P}_{4} \times \mathrm{P}_{1}$ showed significant positive values for all the characters except scape height. These crosses may therefore, be utilized for the study of hybrid vigour and fixation of dominant genes in further breeding research. A similar trend of results was recorded in chilli as observed by Lohithaswa et al., (2000) ${ }^{[24]}$. They studied that out of 45 crosses, 15 crosses showed significant positive SCA effects for fruit yield of which one cross exhibited SCA effects in respect of fruit index, fruit weight, number of fruits per plant; one cross showed SCA for plant height, capsaicin content etc. and so on. The highest SCA value showed by the crosses viz., Kuning $\times$ Tiron, Timor $\times$ Bima Juna, Tiron $\times$ Timor and 
Kuning $\times$ Sibolangit in shallot (Farid et al., 2012) ${ }^{[13]}$ while, the cross AF $\times$ JV12 was the best specific combiner for bulb weight, bulb diameter, total soluble solids, percent bolting, percent doubles, pungency and yield in white onion (Patil and Subramaniam, 2020) [33]. Hosfield et al., (1976, 1977a, 1977b) $[18,19,20]$ generated diallel crosses among inbred lines and observed SCA estimates were moderate to low. Aghora and Pathak (1991) [1] and Joshi and Tandon (1976) [22] reported highly variable SCA estimates among specific crosses.

Genetic component D, which measures additive variation, was highly significant for all the characters except umbel diameter (Table 5). The significant $\mathrm{D}$ indicated the importance of the additive gene effect in controlling of the above characters. A similar result was obtained by Patel et al., (2009) [31] and Basari et al., (2011) ${ }^{[5]}$ in their studied materials. The $\mathrm{F}$ values were non-significant for all the characters except number of umbel, where it was significant indicating the presence of dominant genes. The nonsignificant $\mathrm{F}$ values suggested the presence of an equal amount of dominant and recessive genes in the parents. This result is in agreement with the findings of Deb (2020) ${ }^{[10]}$. The $\mathrm{H}_{1}$ component is significant only for scape height and umbel diameter and the remaining two characters are found to be non-significant. Significant $\mathrm{H}_{1}$ indicated that dominant variation was important for scape height and umbel diameter. Dominant genetic component noted as important by Patel et al., (2009) [31] and Basari et al., (2011) ${ }^{[5]}$ in mung bean and black gram, respectively. But Ahmed et al., (1982) ${ }^{[2]}$ found both additive and dominance genetic effects were important for number of days to fruiting and height, whereas only additive gene effects were important for seed number and fruit weight in chilli. Component $\mathrm{H}_{2}$ is non-significant for all the characters except scape height. Significant $\mathrm{H}_{2}$ value of scape height indicating that dominance with asymmetry of positive and negative effects was present for this respective trait. Chowdhury and Deb (2016) ${ }^{[9]}$ noted both significant and non-significant $\mathrm{H}_{2}$ components in chickpea. $\mathrm{H}_{2}$ is less than $\mathrm{H}_{1}$ for all the characters except number of umbel indicating that dominance effect was important in controlling these three characters and parents contained positive and negative dominant genes in equal proportion. In this investigation, component $\mathrm{h}^{2}$ found to be non-significant for number of umbel, scape height and umbel volume which suggested that dominance effect over all loci in heterozygous phase was not important for these traits. Whereas, the same $\left(h^{2}\right)$ for umbel diameter was significant, indicated that dominance effect over all loci in the heterozygous phase was important. The dominance effect over all loci was in the heterozygous phase for CAMF, NSBMF, NPdPP and NSPP observed by Deb (2020) ${ }^{[10]}$. All the four genetic parameters viz. $\mathrm{D}, \mathrm{H}_{1}, \mathrm{H}_{2}$ and $\mathrm{h}^{2}$ were found to be significant in onion by Ara et at., (2011) ${ }^{[3]}$. The magnitude of E for scape height and umbel volume was lower than the respective values of $\mathrm{D}$ and $\mathrm{H}_{1}$. On the other hand, E was lower than $\mathrm{D}$ but higher than $\mathrm{H}_{1}$ for number of umbel. The vice-versa result was noticed in umbel diameter. The lower values of $\mathrm{E}$ indicated that the environmental influence over the character expression was less than additive and dominant effects.

In the present study, the ratio of $\left(\mathrm{H}_{1} / \mathrm{D}\right)^{1 / 2}$ suggested over dominance for the character scape height and umbel diameter, whereas partial dominance was recorded for the remaining two characters. The same results were observed for $\mathrm{V}_{1} \mathrm{~L}_{1} /$ $\mathrm{W}_{0} \mathrm{~L}_{0}$ ratio. Singh and Rai (1986) ${ }^{[36]}$ reported that in $8 \times 8$ half diallel crosses in chilli where partial dominance was important for fruit length, fruit number per plant and fruit yield per plant. Even El-Ahmadi and Stevens (1979b) ${ }^{[11]}$ also reported similar findings of partial dominance for flowers per cluster and percent fruit set in tomato. On the other hand, over dominance was noted by Karami (2011) ${ }^{[23]}$ and Deb (2020) ${ }^{[10]}$ in chickpea. Chowdhury and Deb (2016) ${ }^{[9]}$ observed partial to over dominance in lentil. The proportion, $\mathrm{H}_{2} / 4 \mathrm{H}_{1}$ measures average value of positive and negative genes i.e., uv over all loci in the parents. In case of unequal allelic frequencies i.e., $\mathrm{u} \neq \mathrm{v}$ at all loci estimated from the ratio $\mathrm{H}_{2} / 4 \mathrm{H}_{1}$ was less than its maximum value 0.25 , which happens when $\mathrm{u}=\mathrm{v}=0.5$ at all loci. Both symmetry and asymmetrical distribution of genes with positive and negative effects were recorded from the estimated value of $\mathrm{H}_{2} / 4 \mathrm{H}_{1}$ in the present investigation for different characters. The values of this ratio studied for scape height, umbel diameter and umbel volume were less than 0.25 indicating unequal distribution of positive and negative alleles. But this ratio greater than 0.25 was recorded only for number of umbel indicated equal distribution of positive and negative alleles. Both unequal and equal gene frequencies were obtained by Basari et al., (2011) [5] and Deb (2020) [10] in black gram and chickpea, respectively. The ratio of $\left[\left(4 \mathrm{DH}_{1}\right)^{1 / 2}+\mathrm{F}\right] /\left[\left(4 \mathrm{DH}_{1}\right)^{1 / 2}-\mathrm{F}\right]$ determines the proportion of dominant and recessive genes in the parents. In this material, the ratio was greater than one was recorded for umbel volume indicated the presence of an excess of dominant genes in the parents. This value for the other three traits is less than one suggested that parents had more recessive than dominant genes. Traits DFF, PHFF, NSBFF, CAMF, NPdPP, NSPP and RW showed excess dominant genes in the parent whereas, traits NPBFF, NSBMF, PdWPP, SWPP and IPW exhibited excess recessive gene than dominant genes in the parents (Deb, 2020) ${ }^{[10]}$ Hong-Pang-Wu (1968b) ${ }^{[17]}$ estimated an equal proportion of dominant and recessive genes for number of primary branches per panicle and panicle length in rice. The ratio of $h^{2} / \mathrm{H}_{2}$, estimates the number of effective factors or groups of genes, which control the character exhibiting the degree of dominance. All the four characters having this ratio smaller than one indicated the involvement of at least one group of dominant genes are responsible for their genetic control and this has happened may be due to non-isodirectional distribution of dominant genes with positive and negative effects. Ara et al., (2011) [3] observed two to one group of genes are responsible to control the inherited traits in onion. Rahman and Eunus (1971) ${ }^{[35]}$ also reported 1 to 21 effective factors for the control of quantitative traits in jute. Only one group of dominant genes was detected to control some agronomic characters in chickpea by Deb (2020) ${ }^{[10]}$.

\section{Conclusion}

The combing ability analysis in onion showed that GCA and SCA variances with each parent played a significant role in the choice of parents regarding all four seed-yield contributing characters. The parent $\mathrm{P}_{4}$ was a good general combiner for scape height, umbel volume and number of umbel. The best combiner as observed from SCA effects in both of $\mathrm{F}_{1}\left(\mathrm{P}_{3} \times \mathrm{P}_{4}, \mathrm{P}_{1} \times \mathrm{P}_{2}, \mathrm{P}_{1} \times \mathrm{P}_{4}, \mathrm{P}_{1} \times \mathrm{P}_{5}\right.$ and $\left.\mathrm{P}_{1} \times \mathrm{P}_{3}\right)$ and reciprocal crosses $\left(\mathrm{P}_{2} \times \mathrm{P}_{1}, \mathrm{P}_{3} \times \mathrm{P}_{1}\right.$ and $\left.\mathrm{P}_{4} \times \mathrm{P}_{1}\right)$ for different characters. The above parent and crosses appeared to be important and indicating that these crosses would likely help do a successful breeding plan easily for the improvement of potential varieties in onion. 


\section{Acknowledgment}

Authors express their heartfelt depth respect to Late Professor Dr. Md. Abdul Khaleque of the Department of Botany, University of Rajshahi, Rajshah-6205, Bangladesh for the technical discussion during carrying out the experiment and data analysis.

\section{Disclosure Statement}

No potential conflict of interest was reported by the authors.

\section{Research ID}

ORCID: https://orcid.org/0000-0002-9574-1041

Scopus Author ID: 57213581258

Web of Science Researcher ID: AAS-6174-2020

Table1: ANOVA of five-parent full diallel of four agronomic traits in onion.

\begin{tabular}{|c|c|c|c|c|c|c|c|c|c|c|c|}
\hline \multirow{2}{*}{ Source } & & \multicolumn{5}{|c|}{ Number of umbel } & \multicolumn{5}{|c|}{ Scape height $(\mathrm{cm})$} \\
\hline & df & SS & MS & $\mathbf{V R}_{1}$ & $\mathbf{V R}_{2}$ & $\mathbf{V R}_{3}$ & SS & MS & $\mathbf{V R}_{1}$ & $\mathbf{V R}_{2}$ & $\mathbf{V R}_{3}$ \\
\hline Treatment & 74 & 1183.2 & 15.9892 & $9.1908 * *$ & $9.4449 * *$ & $9.2252 * *$ & 62396.877 & 843.2010 & $3.5563 * *$ & $8.7769 * *$ & $3.8742 * *$ \\
\hline Replication & 2 & 3.612 & 1.806 & $1.0381^{\mathrm{ns}}$ & $1.0668^{\mathrm{ns}}$ & $1.0420^{\mathrm{ns}}$ & 803.417 & 401.7085 & $1.6943^{\mathrm{ns}}$ & $4.1814 *$ & $1.8457^{\mathrm{ns}}$ \\
\hline Crosses (including parents) & 24 & 1098.33 & 45.7638 & $26.3056 * *$ & $27.0328 * *$ & $26.4066^{* * *}$ & 56982.077 & 2374.253 & $10.0138 * *$ & $24.7136 * *$ & $10.9088 * *$ \\
\hline $\mathrm{C} \times \mathrm{R}$ & 48 & 81.258 & 1.6929 & & & & 4611.403 & 96.0709 & & & \\
\hline Within error & 300 & 521.900 & 1.7397 & & & & 71129.474 & 237.0982 & & & \\
\hline \multirow{2}{*}{ Pooled error } & 348 & 603.158 & 1.7332 & & & & 75740.877 & 217.6462 & & & \\
\hline & & \multicolumn{5}{|c|}{ Umbel diameter $(\mathrm{cm})$} & \multicolumn{4}{|c|}{ Umbel volume $\left(\mathrm{cm}^{3}\right)$} & \\
\hline Treatment & 74 & 268.082 & 3.6227 & $5.9040 * *$ & $3.7518 * *$ & $5.4715 * *$ & 13697.86 & 185.1062 & $14.3690 * *$ & $2.2484 * *$ & \\
\hline Replication & 2 & 0.1314 & 0.0657 & $0.1071^{\mathrm{ns}}$ & $0.0680^{\mathrm{ns}}$ & $0.0992^{\mathrm{ns}}$ & 249.412 & 124.706 & $9.6804 * *$ & $1.5147^{\mathrm{ns}}$ & \\
\hline Crosses (including parents) & 24 & 221.6 & 9.2333 & $15.048 * *$ & $9.5622 * *$ & $13.9454 * *$ & 9496.656 & 395.694 & $30.7161 * *$ & $4.8063 * *$ & \\
\hline $\mathrm{C} \times \mathrm{R}$ & 48 & 46.3506 & 0.9656 & & & & 3951.792 & 82.329 & & & \\
\hline Within error & 300 & 184.068 & 0.6136 & & & & 3864.696 & 12.8823 & & & \\
\hline Pooled error & 348 & 230.4186 & & & & & & & & & \\
\hline
\end{tabular}

$*$ and ** indicates significant at 5\% and $1 \%$ level, respectively and NS indicate non-significant

Table 2: ANOVA of combining ability (GCA and SCA) of four agronomic traits in onion.

\begin{tabular}{|c|c|c|c|c|c|}
\hline \multirow{2}{*}{ Sources } & df & $\begin{array}{c}\text { Number } \\
\text { ofumbel }\end{array}$ & $\begin{array}{c}\text { Scape } \\
\text { height }(\mathbf{c m})\end{array}$ & $\begin{array}{c}\text { Umbel } \\
\text { diameter }(\mathbf{c m})\end{array}$ & $\begin{array}{c}\text { Umbel } \\
\text { volume }\left(\mathbf{c m}^{\mathbf{3}}\right)\end{array}$ \\
\hline GCA & 4 & $7.9504^{* *}$ & $140.0184^{* *}$ & $1.4517^{* *}$ & $98.8200^{* *}$ \\
\hline SCA & 10 & $0.6949^{* *}$ & $81.7583^{* *}$ & $0.2957^{* *}$ & $12.6793^{*}$ \\
\hline Reciprocal & 10 & $3.59623^{* *}$ & $101.5621^{* *}$ & $0.5856^{* *}$ & $10.7056^{\text {ns }}$ \\
\hline Error & 48 & 0.1067 & 3.5906 & 0.0569 & 5.5714 \\
\hline
\end{tabular}

$*$ and $* *$ indicates significant at $5 \%$ and $1 \%$ level, respectively and

NS indicate non-significant
Table 3: Estimated values of general combining ability (GCA) effects of four agronomic traits in onion.

\begin{tabular}{|c|c|c|c|c|}
\hline Parents & $\begin{array}{c}\text { Number of } \\
\text { umbel }\end{array}$ & $\begin{array}{c}\text { Scape height } \\
(\mathbf{c m})\end{array}$ & $\begin{array}{c}\text { Umbel } \\
\text { diameter }(\mathbf{c m})\end{array}$ & $\begin{array}{c}\text { Umbel } \\
\text { volume }\left(\mathbf{c m}^{\mathbf{3}}\right)\end{array}$ \\
\hline $\mathrm{P}_{1}$ & $0.2489^{*}$ & $1.4873^{*}$ & $0.0844^{\mathrm{NS}}$ & $0.0200^{\mathrm{NS}}$ \\
\hline $\mathrm{P}_{2}$ & $-1.1081^{* *}$ & $-7.5727^{*}$ & $-0.3103^{*}$ & $-2.3133^{*}$ \\
\hline $\mathrm{P}_{3}$ & $-0.7311^{* *}$ & $-7.2727^{* *}$ & $-0.4736^{*}$ & $-3.7800^{*}$ \\
\hline $\mathrm{P}_{4}$ & $1.0085^{* *}$ & $7.2873^{* *}$ & $0.2851^{*}$ & $3.8867^{*}$ \\
\hline $\mathrm{P}_{5}$ & $0.5819^{* *}$ & $6.0707^{* *}$ & $0.4144^{*}$ & $2.1867^{*}$ \\
\hline
\end{tabular}

$*$ and $* *$ indicates significant at $5 \%$ and $1 \%$ level, respectively and

NS indicate non-significant

Table 4: Estimated values of specific combining ability (SCA) effects of $F_{1}$ 's and reciprocals of four agronomic traits in onion.

\begin{tabular}{|c|c|c|c|c|c|c|c|c|c|}
\hline \multicolumn{5}{|c|}{ SCA values of F's } & \multicolumn{5}{|c|}{ SCA values of reciprocals } \\
\hline \begin{tabular}{c|c|} 
Crosses \\
$+\times$ & $\lambda$ \\
&
\end{tabular} & $\begin{array}{c}\text { Number of } \\
\text { umbel }\end{array}$ & \begin{tabular}{|c|}
$\begin{array}{c}\text { Scape height } \\
(\mathrm{cm})\end{array}$ \\
\end{tabular} & $\begin{array}{c}\text { Umbel diameter } \\
(\mathbf{c m})\end{array}$ & $\begin{array}{c}\text { Umbel volume } \\
\left(\mathrm{cm}^{3}\right)\end{array}$ & $\begin{array}{c}\text { Crosses } \\
+\times \lambda\end{array}$ & $\begin{array}{c}\text { Number of } \\
\text { umbel }\end{array}$ & \begin{tabular}{|c|}
$\begin{array}{c}\text { Scape height } \\
(\mathrm{cm})\end{array}$ \\
\end{tabular} & $\begin{array}{c}\text { Umbel diameter } \\
(\mathrm{cm})\end{array}$ & $\begin{array}{c}\text { Umbel volume } \\
\left(\mathrm{cm}^{3}\right)\end{array}$ \\
\hline \begin{tabular}{|l|}
$\mathrm{P}_{1} \times \mathrm{P}_{2}$ \\
\end{tabular} & $0.0978^{\mathrm{NS}}$ & $6.4160^{* *}$ & $-0.3697^{*}$ & $0.3133^{\mathrm{NS}}$ & $\mathrm{P}_{2} \times \mathrm{P}_{1}$ & $1.8000^{* * *}$ & $10.733 * *$ & \begin{tabular}{|c|}
$0.3433^{*}$ \\
\end{tabular} & $2.8333 *$ \\
\hline $\mathrm{P}_{1} \times \mathrm{P}_{3}$ & $-0.2942^{\mathrm{NS}}$ & $5327 * *$ & $0136^{\mathrm{NS}}$ & $-0.5533^{\mathrm{NS}}$ & $\mathrm{P}_{3} \times \mathrm{P}_{1}$ & $1.8517 * *$ & $9.1500 * *$ & $0.5967^{*}$ & $-0.5000^{\mathrm{NS}}$ \\
\hline $\mathrm{P}_{1} \times \mathrm{P}_{4}$ & $0.2478^{\mathrm{NS}}$ & $-0.0773^{\mathrm{NS}}$ & $2049^{\mathrm{NS}}$ & $4.6133^{*}$ & $\mathrm{P}_{4} \times \mathrm{P}_{1}$ & $1.0667 * *$ & $1.3667^{\mathrm{NS}}$ & $0.2867^{*}$ & $3.3333 * *$ \\
\hline $\mathrm{P}_{1} \times \mathrm{P}_{5}$ & $0.5411 *$ & $3.7060^{* *}$ & $3389^{*}$ & $4800^{\mathrm{NS}}$ & $\mathrm{P}_{5} \times \mathrm{P}_{1}$ & $0.4000^{*}$ & $0.8000^{\mathrm{NS}}$ & $-0.1967 *$ & $2.5000 *$ \\
\hline $\mathrm{P}_{2} \times \mathrm{P}_{3}$ & $0.0445^{\mathrm{NS}}$ & $-8.8907 * *$ & $-0.3084 *$ & $1.4467^{\mathrm{NS}}$ & $\mathrm{P}_{3} \times \mathrm{P}_{2}$ & $-0.1000^{\mathrm{NS}}$ & $-1.5333^{*}$ & $0.0200^{\mathrm{NS}}$ & $2.5000 *$ \\
\hline $\mathrm{P}_{2} \times \mathrm{P}_{4}$ & $-0.9952 * *$ & $-0.3673^{\mathrm{NS}}$ & $-0.5104 *$ & $-1.8867^{\mathrm{NS}}$ & $\mathrm{P}_{4} \times \mathrm{P}_{2}$ & $-1.5333 * *$ & $-12.250 * *$ & $-0.8367 * *$ & $-3.8333^{*}$ \\
\hline $\mathrm{P}_{2} \times \mathrm{P}_{5}$ & $0.1315^{\mathrm{NS}}$ & $0.9660^{\mathrm{NS}}$ & $0.0069^{\mathrm{NS}}$ & $-3.0200^{*}$ & $\mathrm{P}_{4} \times \mathrm{P}_{3}$ & $-1.3667 * *$ & $-2.7000^{*}$ & $-0.7733 * *$ & $-0.8333^{\mathrm{NS}}$ \\
\hline $\mathrm{P}_{3} \times \mathrm{P}_{4}$ & $0.9278 * *$ & $7.8827 * *$ & $0.2029^{\mathrm{NS}}$ & $-2.4200^{\mathrm{NS}}$ & $\mathrm{P}_{5} \times \mathrm{P}_{2}$ & $-1.9667 * *$ & $-9.8667 * *$ & $-0.2900^{*}$ & $-1.6667^{\mathrm{NS}}$ \\
\hline $\mathrm{P}_{3} \times \mathrm{P}_{5}$ & $-0.8122 * *$ & $-6.8673 * *$ & $-0.0831^{\mathrm{NS}}$ & $0.1133^{\mathrm{NS}}$ & $\mathrm{P}_{5} \times \mathrm{P}_{3}$ & $-1.0667 * *$ & $-7.000 *$ & $-0.9633 * *$ & $-1.6667^{\mathrm{NS}}$ \\
\hline $\mathrm{P}_{4} \times \mathrm{P}_{5}$ & $0.0981^{\mathrm{NS}}$ & $2.0060 * *$ & $-0.1217^{\mathrm{NS}}$ & $-0.0533^{\mathrm{NS}}$ & $\mathrm{P}_{5} \times \mathrm{P}_{4}$ & $-0.8833^{* *}$ & $-0.5667^{\mathrm{NS}}$ & $0.1500^{\mathrm{NS}}$ & $-0.8333^{\mathrm{NS}}$ \\
\hline
\end{tabular}

$*$ and $* *$ indicates significant at $5 \%$ and $1 \%$ level, respectively and NS indicate non-significant

Table 5: Components of variation and their ratios of four agronomic traits in onion

\begin{tabular}{|c|c|c|c|c|c|c|}
\hline \multirow{3}{*}{ Notation } & \multicolumn{3}{|c|}{\begin{tabular}{|l|} 
Number of umbel \\
\end{tabular}} & \multicolumn{3}{|c|}{\begin{tabular}{|l|} 
Scape height $(\mathbf{c m})$ \\
\end{tabular}} \\
\hline & \multirow{2}{*}{\begin{tabular}{|c|} 
Components of variation \\
Estimated values
\end{tabular}} & \multicolumn{2}{|c|}{ Proportional values } & \multirow{2}{*}{\begin{tabular}{|c|} 
Components of variation \\
Estimated values \\
\end{tabular}} & \multicolumn{2}{|c|}{ Proportional values } \\
\hline & & Proportion & $\begin{array}{c}\text { Estimated } \\
\text { values }\end{array}$ & & Proportion & $\begin{array}{c}\text { Estimated } \\
\text { values }\end{array}$ \\
\hline $\mathrm{D}$ & $1.5354 \pm 0.1634$ & $\left(\mathrm{H}_{1} / \mathrm{D}\right)^{1 / 2}$ & 0.21474 & $103.1782 \pm 30.3522$ & $\left(\mathrm{H}_{1} / \mathrm{D}\right)^{1 / 2}$ & 1.496916 \\
\hline $\mathrm{F}$ & $-1.4718 \pm 0.4083$ & $\mathrm{H}_{2} / 4 \mathrm{H}_{1}$ & 0.68008 & $-12.3194 \pm 75.8197$ & $\mathrm{H}_{2} / 4 \mathrm{H}_{1}$ & 0.174735 \\
\hline $\mathrm{H}_{1}$ & $0.0708 \pm 0.4414$ & \multirow{2}{*}{$\left(4 \mathrm{DH}_{1}\right)^{1 / 2}+\mathrm{F} /\left(4 \mathrm{DH}_{1}\right)^{1 / 2}-\mathrm{F}$} & \multirow{2}{*}{-0.38119} & $231.1975 \pm 81.9696$ & \multirow{2}{*}{$\left(4 \mathrm{DH}_{1}\right)^{1 / 2}+\mathrm{F} /\left(4 \mathrm{DH}_{1}\right)^{1 / 2}-\mathrm{F}$} & \multirow{2}{*}{0.9233} \\
\hline $\mathrm{H}_{2}$ & $0.1926 \pm 0.4003$ & & & $161.5937 \pm 74.3473$ & & \\
\hline $\mathrm{h}^{2}$ & $-0.3699 \pm 0.2703$ & $\mathrm{~h}^{2} / \mathrm{H}_{2}$ & -1.92056 & $21.7437 \pm 50.1953$ & $\mathrm{~h}^{2} / \mathrm{H}_{2}$ & 0.1345578 \\
\hline $\mathrm{E}$ & $0.5800 \pm 0.0667$ & $\mathrm{~V}_{1} \mathrm{~L}_{1} / \mathrm{WoLo}_{1}$ & 0.8928 & \begin{tabular}{|l|l}
$15.6153 \pm 12.3912$ & \\
\end{tabular} & $\mathrm{~V}_{1} \mathrm{~L}_{1} / \mathrm{WoLo}_{1}$ & 1.66187 \\
\hline \multicolumn{4}{|c|}{ Umbel diameter $(\mathrm{cm})$} & \multicolumn{3}{|c|}{ Umbel volume $\left(\mathrm{cm}^{3}\right)$} \\
\hline $\mathrm{D}$ & $0.1006 \pm 0.0553$ & $\left(\mathrm{H}_{1} / \mathrm{D}\right)^{1 / 2}$ & 2.0094 & \begin{tabular}{|l|l}
$37.6685 \pm 4.6049$ & \\
\end{tabular} & $\left(\mathrm{H}_{1} / \mathrm{D}\right)^{1 / 2}$ & 0.76599 \\
\hline
\end{tabular}




\begin{tabular}{|c|c|c|c|c|c|c|}
\hline $\mathrm{F}$ & $-0.1776 \pm 0.1382$ & $\mathrm{H}_{2} / 4 \mathrm{H}_{1}$ & 0.13214 & $2.7366 \pm 11.5031$ & $\mathrm{H}_{2} / 4 \mathrm{H}_{1}$ & 0.18969 \\
\hline $\mathrm{H}_{1}$ & $0.4062 \pm 0.1494$ & $\left(4 \mathrm{DH}_{1}\right)^{1 / 2}+\mathrm{F} /\left(4 \mathrm{DH}_{1}\right)^{1 / 2}-\mathrm{F}$ & 0.3896 & $22.1017 \pm 12.4361$ & $\left.\left(4 \mathrm{DH}_{1}\right)^{1 / 2}+\mathrm{F} /(4 \mathrm{DH})_{1}\right)^{1 / 2}-\mathrm{F}$ & 1.0996 \\
\hline $\mathrm{H}_{2}$ & $0.2147 \pm 0.1355$ & & & $16.7700 \pm 11.2797$ & & \\
\hline $\mathrm{h}^{2}$ & $0.1746 \pm 0.0815$ & $\mathrm{~h}^{2} / \mathrm{H}_{2}$ & 0.0000813 & $-1.9938 \pm 7.6155$ & $\mathrm{~h}^{2} / \mathrm{H}_{2}$ & -0.11889 \\
\hline $\mathrm{E}$ & $0.2143 \pm 0.0226$ & $\mathrm{~V}_{1} \mathrm{~L}_{1} / \mathrm{WoLo}$ & 2.1781 & $4.5410 \pm 1.880$ & $\mathrm{~V}_{1} \mathrm{~L}_{1} / \mathrm{WoLo}_{1}$ & 0.89111 \\
\hline
\end{tabular}

\section{References}

1. Aghora T, Pathak CS. Heterosis and combining ability in a line $\times$ tester cross of onions (Allium cepa L.). Veg. Sci. (India) 1991;18(1):53-58.

2. Ahmed N, Singh J, Virk DS, Ahmed N. Inheritance of some quantitative characters in chilli pepper (Capsicum annum L.), II. Earliness, seed number, fruit height and plant height. Capsicum Newsletter 1982;1:31.

3. Ara R, Khaleque MA, Deb AC. Gene action of bulb yield contributing characters in onion (Allium cepa L.). Indian Biologist 2011; 43(1-2):63-73.

4. Augusti KT. Effect of alloxan diabetes of allyl propyl disulphide obtained from onion. Naturwissenschaften 1974;61(4):172-1733. DOI: 10.1007/BF00602600

5. Basari R, Samad MA, Deb AC, Khaleque MA. Diallel analysis of soluble protein in root nodules and seeds in blackgram [Vigna mungo (L.) Hepper]. J Biodiv. Environ 2011;1(2):7-15.

6. BBS. Year Book of Agricultural Statistics. Bangladesh Bureau of Statistics. Ministry of Planning, Government of the People's Republic of Bangladesh, Dhaka 2018, pp.40-143.

7. Brahmachari HD, Augusti KT. Effects of orally effective hypoglycemic agents from plants on alloxan diabetes. J. Pharm. Pharmacol 1962;14:617.

8. Brewster JL. The genetics and plant breeding of Allium crops. In: Onions and their vegetable Allium, CAB International, Wallingford, U.K 1994, 41-62.

9. Chowdhury AR, Deb AC. Study of combining ability and components of variation of yield of some lentil lines. J. Life Earth Sci 2016;11:23-30.

10. Deb AC. Genetic pattern analysis of some quantitative traits in lentil (Lens culinaris Medic.), Vegetos 2020;33(3):580-591.

DOI: https://doi.org/10.1007/s42535-020-00142-5

11. El-Ahmadi AB, Stevens MA. Genetics of high temperature fruit set in the tomato. J. Amer. Soc. Hort. Sci 1979b;104:691-696.

12. FAO. FAO Bulletin of Statistics. Food and Agriculture Organization of the United Nations, Rome, Italy 2001;2(2):97.

13. Farid N, Sugiharto AN, Herison C, Purwito A, Sutjahjo $\mathrm{SH}$. Analysis of combining ability, heterosis effect and heritability estimate of yield-related characters in shallot (Aliumcepa var. ascalonicum Baker). Agrivita 2012;34(1):36-43.

14. Griffing B. Concepts of general and specific combining ability in relation to diallel crossing systems. Aust. J. Biol. Sci 1956;9:463-493.

15. Hayman BI. The analysis of variance of diallel table. Biometrics 1954a; 10:235-244.

16. Hayman BI. The theory of analysis of diallel crosses. Genetics 1954b;39:789-809.

17. Hong-Pang-Wu. Studies of the quantitative inheritance of Oryza sativa L. II. A Diallel analysis for panicle number, tiller number, panicle length, spikelet number and number of primary branches in $\mathrm{F}_{1}$ progeny. Bot. Bul. of Aca. Sinica 1968b;9(2):124-138.
18. Hosfield G, Vest G, Peterson C. A ten-parent diallel cross to evaluate inbred line performance and combining ability in onions. J. Amer. Soc. Hort. Sci 1976;101:324329.

19. Hosfield G, Vest G, Peterson C. A seven-parent diallel cross in onions to evaluate general and specific combining ability and their interaction with years and locations. J. Amer. Soc. Hort. Sci 1977a;102:56-61.

20. Hosfield G, Vest G, Peterson C. Heterosis and combining ability in a diallel cross of onions. J. Amer. Soc. Hort. Sci 1977b;102:355-360.

21. HRDP. Training Manual: Winter Vegetables and Spices Production. Horticulture Research and Development Project (FAO /UNDP/As DB Project. BGD/87/025) and Research and Development Project (FAO/UNDP/As DB Project. BGD/87/025) and BADC, Dhaka 1995, Bangladesh; pp. 27.

22. Joshi H, Tandon J. Heterosis for yield and its genetic basis in onion. Indian J. Agr. Sci 1976;46:88-92.

23. Karami E. Genetic analysis of some agronomic characters in chickpea (Cicer aretinum L.). African Journal of Agricultural Research 2011;6(6):1349-1358.

24. Lohithaswa HC, Kulkarni RS, Manjunath A. Combining ability analysis for fruit yield, capsaicin and other quantitative fruits in chilli (Capsicum annum L.) over environments. Indian J Genet 2000;60(4):511-518.

25. Mani VP, Chauhan VS, Joshi HC, Tandon JP. Exploiting gene effects for improving bulb yield in onion. Indian $\mathrm{J}$. Genet 1999;59(4):511-14.

26. Manjunath BL. Allium cepa Linn. and Allium sativum Linn. in the wealth of India, Raw Material. Vol.1, p. 56. (Manjunath B.L.) Eds. Council of Scientific and Industrial Res. Govt. India, Delhi 1948.

27. Mather K. Biometrical Genetics ( $1^{\text {st }}$ eds.), Mathuen and Co. Ltd. London 1949.

28. Mila FA, Parvin MT. Forecasting area, production and yield of onion in Bangladesh by using ARIMA model. AJAEES DOI:10.9734/AJAEES/2019/v37i430274.

29. Nadkarni KN. Allium cepa Linn and Allium sativum Linn. In: Indian MateriaMedica, $3^{\text {rd }}$ Eds. (Part1) (Puranik MV and Bhatcal GR Eds.). Popular Book Depot, Bombay, India 1954, pp. 63.

30. Pandey UC, Singh JS. Agro techniques for onion and garlic. In: Advances in Horticulture-Vegetables Crops: Part 1 Eds. : KL Chadha and G Kalloo, Malhotra Publishing House, New Delhi, India 1993;5:434-450.

31. Patel M, Patel B, Savaliya J, Tikka S. Heterosis and genetic architecture of yield, yield contributing traits and yellow mosaic virus in mungbean [Vigna radiata (L.) Wilczek]. Legume Research-An International Journal 2009;32(4):260-264.

32. Pathak CS, Gowda VR. Improvement of onion. In: Advances in Horticulture-Vegetables Crops: Part 1. Eds. KL Chadha and G Kalloo, Malhotra Publishing House, New Delhi, India 1993;5:181-199.

33. Patil DG, Subramaniam VR. Combining ability analysis for yield and processing qualities in white onion (Allium cepa L.). Curr. Agri. Res 2020;8(1):18-24. 
34. Rahim MA. Onion cultivation in Bangladesh: Problems, research and future prospects. Allium improvement Newsletter 1991;1:1-14.

35. Rahman MA, Eunus AM. Inheritance of earliness and plant height in a twelve-parent diallel cross of upland jute. Acta Agronomica 1971;20:363-375.

36. Singh RP, Rai AK. Diallel analysis of fruit yield and its components in chilli. Madras Agricultural Journal 1986;73(2):87-91. 